\title{
Large Solitary Non Paracytic Cyst of Liver: Management by External Drainage
}

\author{
Vivek Agrawal*, Kumar Krishnan**
}

\begin{abstract}
Abstrak
Sejak Michel melaporkan kasus kista hati pertama pada 1856, banyak laporan tentang kista hati nonparasitik tanpa komplikasi dijumpai dalam kepustakaan. Penyakit ini umumnya asimtomatik, kecuali jika ada komplikasi atau membesar. Pielografi intravena perlu dilakukan untuk menyingkirkan adanya patologi pada ginjal. Hasil memuaskan diperoleh dengan memasang drainase dengan bimbingan radiologik. Tidak diperlukan anestesi umum atau laparotomi. Kateter dipertahankan selama 2-3 bulan.
\end{abstract}

\begin{abstract}
s
Ever since in 1856 when Michel reported the first case of hepatic cyst, much literature has been added on the solitary uncomplicated nonparacytic cystic disease of the liver. This distinct disease entity remains largely asymptomatic unless it presents by virtue of its size or complications. Intravenous pyelogram should be mandatory to rule out any associated renal pathology. Instead of resorting to surgery in all cases, placement of radiologically guided external dependent drainage catheter yields good results with excellent patient compliance as no general anesthesia or laparotomy is required. For cure, only a tube coming out of the abdomen is to be endured for 2-3 months.
\end{abstract}

Keywords : Simple Hepatic Cyst, Cystic Disease of Liver, Cystic Hepatomegaly

Cystic lesions of the liver affect females predominantly and are universally encountered in clinical practice. 1,2 They are either solitary or multiple, affecting the right lobe more often, ${ }^{3}$ and are distinct from its polycystic disease which is usually associated with polycystic disease of the kidney, and less commonly, the pancreas. ${ }^{4}$ The origin of these cysts is thought to be as a result of embryonal maldevelopment in form on noncanalization of proximal and distal anlage ${ }^{5}$ or sequestration of aberrant ducts which become cystic by either infection or hyperplasia and degeneration. ${ }^{6}$ These cysts are an incidental finding in $0.5 \%$ of all

* Department of Surgery University College of Medical Sciences \& Guru Teg Bahadur Hospital, Delhi, India

** Department of Surgery Jawaharlal Institute of Post Graduate Medical Education and Research (Jipmer), Pondicherry, India autopsies ${ }^{7}$ and symptoms arise in one third ${ }^{8}$ because of either large size causing pressure effects or when complications ${ }^{9}$, like rupture, infection, haemorrhage or malignant transformation, occurs.

Various modalities of surgery ${ }^{1}$ are practiced for management of symptomatic cysts (eg.) external drainage, marsupialization, excision, internal drainage through Roux-en-Y cystoenteric anastomosis, and hepatic resection. Goldstein ${ }^{10}$ was first to aspirate and do sclerotherapy by instilling pantopaque. Similar good results are reported by Romer ${ }^{11}$ who stated that surgery should be reserved for cysts which recur or fail to resolve. External drainage ${ }^{12}$ is safe and effective way to manage uncomplicated cysts. Though it takes a long time for resolution, it is easily accepted by patients and is free of complication. Progress of healing can be assessed by ultrasound and cavitograms (contrast X-rays through tube). Omentoplasty can be done, if residual cavity persists, at a later date. ${ }^{13}$ 


\section{CASE REPORT}

A 32 year old housewife from Andhra Pradesh, India presented with distension and dragging pain in abdomen for past 3 months. There was no icterus, pallor or pedal oedema. JVP was not raised. Abdomen showed fullness in upper $2 / 3 \&$ fingers could be insinuated under the right subcostal margin. The mass was smooth, cystic with a fluid thrill, having a firm inferior border moving very well with respiration. This mass was bimanually palpable but could not be pushed in the right renal angle. A provisional diagnosis of either hydronephrosis of right kidney or hydatid disease of liver was made. Routine blood investigations were normal. Casoni's and IHA for hydatid serology were negative. $X$ - ray chest showed raised right dome of diaphragm and $\mathrm{x}$-ray abdomen showed soft tissue opalescence in upper $2 / 3$. IVP showed a low placed right kidney with nonvisualization of upper calyces. However, USG abdomen revealed solitary uniloculated liver cyst containing debris; normal kidney structure.

A decision of exploratory laparotomy was undertaken. The kidney was normal on palpation. A large hepatic cyst was seen pointing on the posterio-superior surface of the right lobe. The cavity was drained of its 8 litres of clear fluid which became blood tinged later-due to either cyst collapse or operative manipulation. Cystoenteric anastomosis was not done as it was decided that it would not function because of its nondependent site-on the top of the liver. Hepatic resection was not undertaken as enough normal liver tissue was present and apparently no features of malignant transformation were seen. ${ }^{14}$ An externally draining Malecot's catheter was left in the cavity and brought out sub-costally on the right side in anterior axillary line. Histopathology of the cyst wall showed fibrocollagenous tissue, cell ducts, nerve bundles, numerous blood vessels, inflammatory cells and, possibly, smooth muscle in some areas suggesting a simple cyst of the liver. The subsequent daily drainage is shown in (Fig.1). It reduced to about $400 \mathrm{ml}$ per $24 \mathrm{hr}$. by the 5 th day.

Sclerotherapy with intracavitory tetracycline solution was attempted on 11 th and 14th days but rebound increase of daily output to $>1200 \mathrm{ml}$ per $24 \mathrm{hr}$. and occurence of fever and pain prompted abandoning of this therapy. Subsequent drainage fluid cultured E.coli, but no treatment was given as patient had no constitutional symptoms. A radiocontrast cavitogram through the Malecot catheter after 3 wks showed a small cavity. Except for discomfort of the tube, the patient tolerated the therapy well. She was discharged from the hospital after 5 weeks with a daily drainage of $<100 \mathrm{ml}$. and

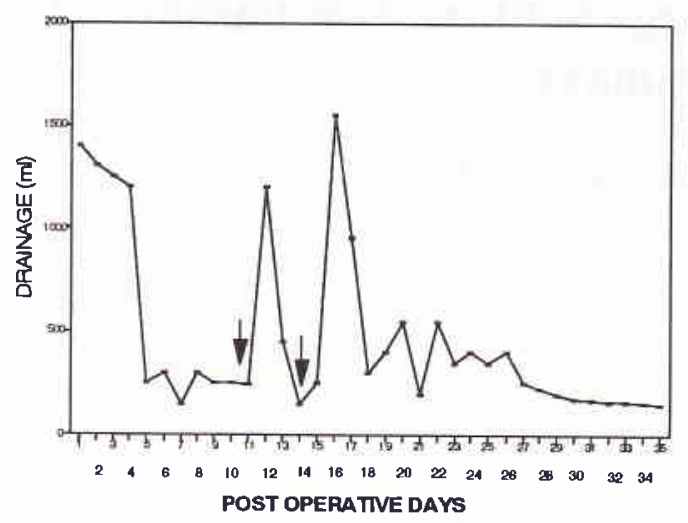

Fig 1. Daily Drainage Chart

adequate instructions for tube care, and to record the daily tube output.

Two months later, the patient came to the surgery outpatient department and stated that the tube had slipped out and that the daily output was $<20 \mathrm{ml}$ at that point of time. A repeat ultrasound showed irregular hyperechoic zone over the right lobe of liver without any cystic area-possibly scar tissue.

\section{CONCLUSION}

For simple uncomplicated symptomatic cysts of the liver the methodology of external drainage, preferably dependent, is a good proposition. Reviewing the above case, the externally draining catheter could have been easily placed through the services of an interventional radiologist, thus avoiding the abdominal scar. It is, therefore, possible to advocate this form of treatment as first line of therapy. ${ }^{11}$ All advantages of this minimal intervention are apparent except that the patient has to bear the tube coming out of the abdomen for an approximate period of 3 months; to which the patient readily agrees as laparotomy under anaesthesia is forgone.

\section{REFERENCES}

1. Haded AR, Westbrook KC, Graham GG, Morris WD, Campbell GS. Symptomatic paracytic liver cysts. Am J Surg 1977; 134: 739-44.

2. Petroski D, Stafford C, Coodley EC. Cystic liver disease with associated hypernephroma. Am J Gastroentrol 1973; 59: 255.

3. Willeamson RCN, Ramns NI, Shorey BA. Congenital solitary cyst of the liver and spleen. Br J Surg 1978; 65: 871 . 
4. Fredman M. Polycystic disease of liver. Am J Gastroenterol 1958; 29: 83-6.

5. Von Mayenburg H. Uiber die cysten leber beitr: Path Anat $1918 ; 64: 477$.

6. Moschowitz E. Non paracytic cyst (congenital) of liver with a study of aberrant bile ducts. Am J Med Sci 1906; 131: 674-99.

7. Sanfelippo PM, Beahrs OH, Weiland LH. Cystic disease of liver. Ann Surg 1974; 179: 922-5.

8. Burch JS, Jones HE. Large nonparacytic cyst of liver simulating ovarian cyst. Am J Obstet Gynecol 1952; 63: 441-4.

9. Ackman FD, Rhea LJ. Non paracytic cyst of liver; their clinical and pathological aspects. Br J Surg 1913; 18: 648-54.
10. Goldstein HM, Carlygle DR, Nelson RS. Treatment of symptomatic hepatic cyst by percutaneous instillation of Pantopaque. Am J Radiol 1976; 127: 850-3.

11. Romer CE, Ferrcci JT, Mueller PR, Simeone JF, van Sonnenberg $\mathrm{E}$, Wittennberg J. Hepatic cysts: Diagnosis and therapy by sonographic needle aspiration. Am J Radiol 1981; 136: 1065-70.

12. Flagg RS, Robinson DW. Solitary non paracytic hepatic cysts. Arch Surg 1967; 95: 964.

13. Goldsmith HS. Omental transplantation. Rev Surg 1967; 24: 379.

14. Americks J, Appleman H, Frey C. Malignant non paracytic Cyst of the liver. Ann Surg 1972; 176: 713. 